Forthcoming at The Journal of Sex Research

\title{
Race and Trends in Pornography Viewership, 1973-2016: Examining the Moderating Roles of Gender and Religion
}

\author{
Samuel L. Perry \\ University of Oklahoma \\ Cyrus Schleifer \\ University of Oklahoma
}

\begin{abstract}
While some research has uncovered racial differences in patterns of pornography viewership, no studies to date have considered how these patterns may be changing over time or how these trends may be moderated by other key predictors of pornography viewership, specifically, gender and religion. Using nationally representative data from the 1973-2016 General Social Surveys ( $N$ $=20,620)$, and taking into account different ethno-religious histories with pornography as a moral issue, we examine how race, gender, and religion intersect to influence trends in pornography viewership over 43 years. Analyses reveal that black Americans in general are more likely to view pornography than whites, and they are increasing in their pornography viewership at a higher rate than whites. Moreover, black men are more likely to consume pornography than all other race-gender combinations, but only differ from white women in their increasing rate of pornography viewership. Lastly, frequent worship attendance only moderates trends in pornography viewership for white men. By contrast, regardless of attendance frequency, black men and women show increasing rates of pornography use while white women show flat rates. We conclude by discussing the implications of these findings for research on the intersections of race, gender, religion, and sexuality.
\end{abstract}

Key words: pornography, race, gender, sexuality, religiosity, trends 


\section{Introduction}

As sexually explicit media or "pornography"1 has grown more mainstream over the past few decades, scholars from a variety of disciplines have scrutinized the messages conveyed in these media about race and sexuality. Some scholars take a highly critical approach, arguing that the caricatures depicted in pornographic films and videos exacerbate racial stereotypes about black (male and female) hypersexuality, Asian female exoticism and subservience, and so on (e.g., Amoah, 1994; Bernardi, 2007; Collins, 2000; Cowan, 1995; Cowan \& Campbell, 2004; Dines, 1998, 2006, 2010; Forna, 1992; Jensen, 2007; Mayall \& Russell, 1993). Other scholars, by contrast, argue that ethnic minority male and female performers in adult films are afforded agency that allows them to challenge racial stereotypes and push the boundaries of sexual propriety in ways that are liberating on balance (e.g., Miller-Young, 2007, 2010, 2014; Nash, 2014; Smith \& Luykx, 2017).

Despite the important contributions of these studies to contemporary debates about race and sexuality, almost all studies in this vein have focused on the "supply side" of pornography. Only rarely, however, have studies considered how race influences the "demand side" of pornography—namely, patterns of pornography viewership — and what these patterns reveal about American society more broadly. While the few studies of pornography consumption that have included measures of racial identity often show similar results (Brown \& L'Engle, 2009;

Buzzell, 2005; Hennessey et al., 2009; Patterson \& Price, 2012; Perry, 2016; Wright, 2013;

Wright, Bae, Funk, 2013), to our knowledge no study has considered how the connection

\footnotetext{
${ }^{1}$ The term "pornography" is difficult to define, and can often carry pejorative moral connotations that are not intended here. While some opt to use more neutral terms like "sexually explicit media," the majority of studies on the topic still prefer "pornography" and thus we use the term. For the purposes of this study, "pornography" will refer to sexually explicit media (magazines, movies, online videos) that are made/viewed with the intention of arousing the viewer.
} 
between race and pornography viewership may be changing over time and how these trends may be moderated by other traditionally strong predictors of pornography viewership, in particular, gender and religious commitment. The current study seeks to fill this lacuna. Using data from representative samples of black and white Americans from the 1973-2016 waves of the General Social Survey (GSS), and taking into account different ethno-religious histories with pornography as a moral issue, the current study considers how race intersects with gender and religious commitment to differentially influence patterns of pornography viewership in the United States, and how these patterns may be changing over the past four decades.

To better frame the current study, in the following sections we first provide an overview of empirical research on the link between race and pornography viewership. This is followed by our theory development from which we generate hypotheses regarding the potential intersecting influences of race, gender, and religion on pornography consumption and how these relationships may be changing over time due to the broader acceptability and availability of pornography in the United States.

\section{Empirical and Theoretical Background}

\section{Empirical Findings on Race and Pornography Consumption}

While numerous studies have considered the social antecedents and correlates of pornography viewership, ethnic or racial identity has seldom if ever been a focal variable, if it has been included at all. Numerous studies focusing on pornography viewership have left race or ethnicity out entirely, often because the studies consisted of essentially mono-racial samples of college students (e.g., Carroll et al., 2008; Nelson, Padilla-Walker, \& Carroll, 2010) or populations in Western European nations where there were very few non-whites (e.g., Hald, 2006; Peter \& Valkenburg, 2011). Others had sufficient numbers of non-whites, but chose not to 
consider race/ethnicity as an important characteristic worth including in analyses or reporting (e.g., Goodson, McCormick, and Evans, 2001; Grubbs et al., 2015; Hardy et al., 2013; Poulsen, Busby, and Galovan, 2013; Price et al., 2016; Short, Kasper, \& Wetterneck, 2015).

Among the studies that have included measures of race or ethnicity in their analysis, the findings have been fairly consistent with non-whites, and black Americans in particular, being more likely to view pornographic material than whites, either at all or in greater frequencies. In non-random samples of adolescents, Hennessey et al. (2009) found black and Hispanic adolescents were more likely to have been exposed to sexual content than whites. And in a similar study of black adolescents, Brown and L'Engle (2009) found that being a black male or black female was associated with exposure to adult magazines, X-rated movies, and Internet pornography. Other studies using nationally-representative samples have reported similar patterns. Using data from the 1994 GSS, Buzzell (2005) showed that black Americans were 17 percent more likely than whites to have viewed pornography in a theater or on a VCR in the previous year. Though they did not interpret their findings, Patterson and Price's (2012) analysis of 1973-2006 GSS data also showed that both black men and women were more likely than whites to report viewing an X-rated movie in the previous year. Looking at pornography viewing frequency, Perry's (2016) analysis of 2006 Portraits of American Life Study data showed that black Americans reported viewing pornography more often than white Americans, but Asian Americans reported viewing pornography less often. And while they did not disaggregate racial categories beyond white and "non-white" (a composite category of "black" and "other"), or control for any confounding factors, Wright and his colleagues (Wright, 2013; Wright et al., 2013) found using 1973-2010 GSS data that non-white men and women were more likely to report viewing X-rated movies than whites, but primarily in later waves of the GSS, suggesting 
that this white/non-white difference in pornography viewership may be growing more pronounced over time.

While these findings suggest empirical patterns, because race/ethnicity was never the explicit focus of such studies, scholars have spent little effort theorizing about why racial minority men and women, and black Americans especially, would be more likely to view pornography than their white counterparts. The following section grounds our theoretical expectations in the different historical relationship white and black Americans have with pornography as a public issue and the different connections that ethno-religious communities draw between religion and sexuality.

\section{Theorizing the Link between Race, Pornography Viewership, and Potential Moderators}

Despite the recent resurgence of sociological research suggesting an underlying biological reality to racial categories (and stemming from this, behavioral differences) (Guo et al., 2014; Shaio et al., 2012), we reject the notion that racial disparities in sexual consumption somehow evidence different essential or biological drives that inhere within "racial groups," which are socially constructed and arbitrarily defined (see Morning, 2014). Moreover, while structural inequalities such as, for example, relatively less parental oversight due to a disproportionate number of single parent families might explain the higher exposure to sexual media among black adolescents (Brown \& L'Engle, 2009; Hennessy et al., 2009), this would not account for racial disparities in sexual consumption among American adults, especially after class characteristics had been held constant (Patterson \& Price, 2012; Perry, 2016). Our theorizing, then, starts from the assumption that sexual norms and behavioral patterns are not only socially learned, but strongly influenced by our location within social environments that are both racialized and gendered. 
While they do not elaborate further or focus on specific racial minority groups, Wright et al. (2013, p. 1132) opine that, "Subcultural differences, such as increased tolerance for sexual expression, may lead non-Whites to consume more pornography than Whites." But where do these subcultural differences regarding sexual expression come from? One potential influence is historically different moral emphases across white and black communities, much of which are grounded in different ethno-religious subcultural characteristics. White Americans, for example, have a unique history with pornography as a public issue, which may constrain their use of pornographic material more so than black Americans. More specifically, white Protestants and Catholics, who make up the majority of white Americans, have been at the forefront of efforts to oppose the distribution of pornography in the United States (Perry, 2017a; Sherkat \& Ellison, 1997; Strub, 2011; Thomas, 2013). Black communities, by contrast, have never targeted pornography use as a key moral issue worth opposing (Wood \& Hughes, 1984), preferring instead to focus on more immediate, structural issues (Pattillo-McCoy, 1998; Shelton \& Emerson, 2012). Thus, it is unsurprising that studies have historically found black Americans being less likely than white Americans to believe pornography should be illegal for all ages or that it causes a societal breakdown in morals (Lykke \& Cohen, 2015; Patterson \& Price, 2012; Sherkat \& Ellison, 1997; Wood \& Hughes, 1984).

Black Americans' relative lack of collective moral objection to pornography leading to fewer internalized norms against pornography use at the individual-level would certainly help explain blacks' greater tendency to view pornography than whites (Brown \& L'Engle, 2009; Buzzell, 2005; Hennessey et al., 2009; Perry, 2016), and would lead us to expect the same in our data. Thus our first general expectation is that:

Hypothesis 1: Black Americans will be more likely to report viewing pornography compared to white Americans. 
But how might gender and religion intersect with race to differentially influence pornography consumption? We consider gender first. Among the most consistent findings in pornography research is that men are far more likely to view pornography than women, and to do so more frequently (Carroll et al., 2008; Perry, 2016; Peterson \& Hyde, 2011; Poulsen et al., 2013; Price et al., 2016; Regnerus et al., 2016; Wright, 2013; Wright et al., 2013). While some scholars suggest that evolutionary biology may play a role, other analyses have shown that much of this gender difference is due to internalized norms of "appropriate" sexual desire and behavior for men and women (Johansson \& Hammaren, 2007; Peterson \& Hyde, 2011). Taking the intersecting influence of gender and race into account, the internalization of dominant conceptions of masculinity, particularly in the black community about male sexual virility and conquest (see Collins, 2000, 2004), might also shape black Americans' pursuit of pornographic media along gender lines. These insights lead to the following expectation:

Hypothesis 2: Black men will be the most likely to view pornography, compared to white men, black women, and white women.

How might religion further moderate the links between race, gender, and pornography use? Beneath the different racial histories with pornography as a public issue, researchers have consistently shown that different ethno-religious communities connect religion and sexual behavior in different ways, which would lead us to expect that religion influences black and white Americans differently with regard to pornography use. For white Christians, religion and traditionalist sexual norms are often closely connected, and thus higher religious commitment is usually quite predictive of sexual behavior patterns (Patterson and Price, 2012; Regnerus, 2007; Wright, 2013; Wright et al., 2013; but see Perry, 2017a). Yet, even though black Americans tend to be more conventionally religious than whites on average (Shelton \& Emerson, 2012), research has shown that black Americans, and especially black men, do not tend to connect their religious 
piety to their sexual norms and behaviors to the extent that whites do (Bearman \& Bruckner, 2001; McCree et al. 2003; Regnerus, 2007; Steinman \& Zimmerman, 2004). These differential patterns of connecting religion and morality to sexual behavior largely stem from what religion has historically meant for different ethno-religious communities. According to Shelton and Emerson (2012), for white Americans, religion has often served to reinforce a traditional, patriarchal, middleclass moral order. Thus, religious participation tends to connect one to traditionalist moral norms regarding sexuality, and strongly influences patterns of sexual behavior. For black Americans, however, having been historically marginalized, religion has been far less a reinforcement of traditionalist sexual norms, and more a means of transcending their current experience of oppression. Based on this research, we would expect that measures of religious participation would moderate the pornography consumption of white Americans, but not black Americans, and least of all black men. We generally hypothesize:

Hypotheses 3: Religious commitment will influence the pornography consumption of white Americans, but not black Americans.

Lastly, while these various influences might differentially shape the demand for pornographic content along lines of race, gender, and religion, another key contribution of our study is showing how these patterns may being changing over time. Following the rise of the Internet in the mid-1990s and the advent of smartphone technology in the mid-2000s, pornography has only become more accessible, affordable, and anonymous. Research also suggests that it has become more publicly acceptable, particularly for American men (Carroll et al., 2008; Lykke \& Cohen, 2015; Price et al., 2016). To the extent that a lack of internalized norms against pornography viewership might influence black Americans, and black men especially, to view pornography at greater rates than their white counterparts, this trend would conceivably increase over time as various barriers to pornography use (cost, convenience, 
stigma, etc.) have been removed. In other words, we expect that those groups whom we already hypothesize would be more likely to consume sexual media (blacks compared to whites and black men compared to everyone else) will show a greater comparative increase in their likelihood of viewing pornography over time as it has become more available and less stigmatized. Stated formally, we expect:

Hypothesis 4: Black Americans will show a higher rate of increase in their likelihood of viewing pornography over time compared whites.

Hypothesis 5: Black men will show a higher rate of increase in their likelihood of viewing pornography over time compared to white men, black women, and white women.

With respect to religion's moderating influence on these patterns over time, because we expect religious commitment to serve as a hindrance to pornography use for white Americans but not black Americans, we lastly expect that:

Hypotheses 6: White Americans who are more religiously committed will not show an increase in pornography viewership across time, but black Americans who are religiously committed will.

\section{Method}

\section{Participants}

Our analyses use data from the cross-sectional GSS, 1973-2016. The GSS is a nationally representative, face-to-face survey of the non-institutionalized, English-Spanish speaking American adult population in the United States. The GSS is funded by the National Science Foundation and has been conducted since 1972 (the 1972 wave did not ask about pornography use). While earlier waves of the GSS were administered roughly every year, since 1994 the GSS surveyed roughly 3,000 Americans in even numbered years. Despite several limitations in measurement (explained below), the GSS is the only data source with questions about pornography consumption spanning several decades, and thus, represents the only available 
source with which to examine patterns in pornography viewership over time and its connection with our factors of interest: race and gender. After accounting for missing data, we have an analytical sample of 20,620 individuals. Descriptive statistics of all variables used in the analyses are included in Table 1.

\section{[TABLE 1 ABOUT HERE]}

\section{Measures}

Pornography Viewership. Our outcome measure for this study is pornography viewership from 1973-2016. Across the past 43 years, the GSS has asked respondents: "Have you seen an X-rated movie in the last year?" We coded responses such that yes $=1$, no $=0$. Overall, 26 percent of white Americans and 35 percent of black Americans report viewing an adult movie during at least one survey wave. We acknowledge at the outset two key limitations of this measure, namely, that the outcome is binary and the wording is rather dated. Despite these limitations, which we discuss in greater detail below, because the survey question has been consistent over this time period it allows us to track trends in pornography viewership across different groups of interest. This outcome has also been widely used in previous studies of pornography consumption over time (Doran \& Price, 2014; Patterson \& Price, 2012; Perry \& Schleifer, 2017; Price et al., 2016; Regnerus, Gordon, \& Price, 2016; Wright, 2013; Wright et al., 2013), and thus, is profitably used here to address our research questions.

Key Predictors. Our key predictor variables are race, gender, and religious commitment. An unfortunate limitation of the GSS is that it has not allowed for a variety of racial categories, but has instead historically placed respondents into white, black, or other. Because we cannot meaningfully interpret the "other" racial category, we have opted to only focus on white and black Americans, coded 0 and 1 respectively. This is not a significant limitation, ultimately, 
since the majority of empirical research on pornography viewership has focused on differences between white and black Americans, and thus, we are able to contribute to that ongoing conversation. For gender, we coded men as 0 and women as 1.

Lastly, for religious commitment, we use a dichotomous measure of religious service attendance, coded $1=$ monthly attendance, $0=$ less than monthly (see Patterson and Price 2012; Voas and Chaves 2016 for similar coding). While we acknowledge that "religious commitment" is a multidimensional construct, worship attendance is often used as a reliable measure of “religiosity" (e.g., Doran \& Price, 2014; Patterson \& Price, 2012; Perry \& Schleifer, 2017; Wright, 2013; Wright et al., 2013) and our use of this dichotomized measure allows us to observe discrete interactive patterns between race and pornography viewership across time that are considerably more interpretable than using a full range of attendance. Additionally, while the GSS includes other measures of religious commitment such as prayer and self-rated religiosity, only religious service attendance has been asked since 1973 and thus allows us to make use of all available GSS survey waves that ask about pornography use. ${ }^{2}$

Control Variables. Our analyses also include a number of control variables following previous research on pornography consumption (Buzzell, 2005; Carroll et al., 2008; Patterson \& Price, 2012; Perry, 2016, 2017b; Wright, 2013; Wright et al., 2013). We include continuous measures of age and age ${ }^{2}$ and equivalized household income. Equivalization, following Brady (2009), is achieved by dividing household income by the square root of the total number of household members and then taking the natural log of this amount. And we include dummy variables for marital status (married $=1$, other $=0$ ), parental status (any children $=1$, other $=0$ ), education (less than bachelors $=0$, bachelors $=1$, advanced degree $=1$ ), region $($ South $=1$, other

\footnotetext{
${ }^{2}$ Ancillary analyses with religious service attendance recoded as $1=$ weekly, $0=$ less than weekly revealed substantively similar results to those we report below (full models available upon request).
} 
$=0$ ), and urban residence (city $=1$, other $=0$ ). While religious tradition is not as closely connected with patterns of pornography viewership as measures of religious commitment (see Perry, 2017a), we also included controls for religious tradition. Conservative Protestants (or “evangelicals") have historically been the most opposed to pornography viewership (Sherkat \& Ellison, 1997; Perry, 2017a; Thomas, 2013) and thus our analysis compares conservative Protestants $(=1)$ to everyone else $(=0)$, classifying "conservative Protestant" with a modified ${ }^{3}$ version of the religious traditions classification scheme proposed by Steensland et al. (2000).

\section{Plan of Analysis}

Because our measure of pornography viewership is binary, we use a series of logistic regression models to capture trend differences across our groups of interest. The multivariate analysis proceeds as follows. Table 2 presents logistic regression models predicting pornography viewership in order to establish differences in viewership across race and gender, and to demonstrate how these differences may be increasing or decreasing over time. Model 1 is the full model without interaction terms. Models 2 and 3 add interaction terms for black $\times$ year and female $\times$ year separately, and Model 4 includes both interaction terms together.

Table 3 predicts pornography viewership with black and white women and men separated into dummy variables (black men, white men, black women, white women) in order to compare pornography viewership across race-gender combinations and to assess whether these differences are increasing over time. Model 1 represents the main effects model while Model 2 includes interaction terms for each race-gender combination $\times$ year with white women as the reference category.

\footnotetext{
${ }^{3}$ The modification involves decomposing the "black Protestants" category into the "mainline" and "evangelical categories" (Schleifer \& Chaves, 2017). This transformation alleviates concerns over collinearity with our racial control variables and we believe better captures the group we call "conservative Protestants."
} 
Lastly, Table 4 predicts pornography viewership across race, gender, worship attendance, and year to assess how religious commitment may differentially influence racial differences in pornography viewership over time. Model 1 provides a model with black $\times$ monthly attendance to test whether religious commitment moderates racial differences in pornography viewership generally. Models 2-4 include triple interaction for the full sample and with men and women separately taking year into account so as to show the moderating influence of religious commitment on race-gender patterns of pornography viewership over time.

All models present coefficients in log odds with standard errors in parentheses, and the figures demonstrating significant interactions present predicted probabilities.

\section{Results}

The bivariate statistics in Table 1 indicate that, over the aggregated 1973-2016 GSS waves, black Americans are roughly 9 percent more likely to report viewing an X-rated movie in the previous year than whites, a significant difference at the .001 level. Consistent with previous research, this greater tendency for black Americans to view pornography compared to whites comes in spite of the fact that black Americans are 18 percent more likely than whites to attend worship services at least monthly (62 percent compared to 44 percent) and are over twice as likely to be conservative Protestants (64 percent compared to 30 percent), all significant differences beyond .001. This would support theories suggesting that black Americans do not tend to connect conventional measures of religious commitment or conservatism to traditionalist sexual norms and behaviors as whites tend to (see Regnerus 2007, p. 121).

Turning to the multivariate analysis, Model 1 in Table 2 indicates that black Americans are indeed more likely than white Americans to view pornography, net of other factors. This affirms our first hypothesis. Unsurprisingly, Americans who are male, not monthly worship 
attendees, not conservative Protestants, younger, urban, and less educated are also more likely to report viewing pornography. The coefficient for "year" is positive and significant indicating that the likelihood that Americans view pornography in the previous year has been increasing over time. Models 2 and 3 introduce the interaction terms for black $\times$ year and female $\times$ year, respectively, and each are statistically significant. Moreover, both retain statistical significance when included together in Model 4. The direction of the interaction terms indicate that black Americans and American men are increasing in their likelihood of viewing pornography over time compared to white Americans and American women, respectively.

Figure 1 clearly illustrates these trends with predicted probabilities. Standard errors are also included. The panel on the left shows that white Americans have increased in their likelihood of viewing pornography from roughly 22 percent to just over 30 percent between 1973 and 2016, an increase of about 8 percent. Black Americans, by contrast, have increased in their likelihood of viewing pornography by roughly 18 percent during that time frame, from 28 percent in 1973 to about 46 percent in 2016. The difference between American men and women is even more pronounced. While American men have increased in their likelihood of viewing pornography by roughly 17 percent, from 26 percent in 1973 to 43 percent in 2016, American women have hardly increased in their pornography viewership at all, staying right around 20 percent. These findings affirm our general theory that Americans who are already more likely to view pornography than others (blacks compared to whites, men compared to women) would show greater rates of pornography viewership over time as pornography has become more accessible and acceptable. Our specific hypothesis about black Americans in particular (hypothesis 4) is thus supported.

[TABLE 2 AND FIGURE 1 ABOUT HERE] 
How does race interact with gender to influence pornography viewership over time? Table 3 presents models predicting pornography viewership with four race-gender combinations and white women as the reference category. All models include the full array of control variables from Table 2, but these are not reported to conserve space (full results available upon request). Model 1 demonstrates that all the race-gender combinations differ from white women in their likelihood of viewing pornography beyond the .001 level. Black males have the highest likelihood of viewing pornography, followed by white men, black women, and white women, and these coefficients are all significantly different from one another at the .001 level and beyond. This affirms our second hypothesis.

Model 2 includes the interaction terms for each race-gender combination $\times$ year and all race-gender combinations are significantly different from white women in terms of their likelihood of viewing pornography across time. In ancillary analyses (available upon request), we alternated the reference categories and while black men were statistically different from all race-gender combinations in their likelihood of viewing pornography, black men were only significantly different from white women in their increasing rate of pornography viewership over time. Thus our fifth hypothesis only receives partial support. Black men were not increasing in their rate of pornography viewership more so than white men or black women.

Figure 2 illustrates the different slopes for each race-gender combination over time. While black men show the greatest likelihood of viewing pornography (followed by white men, then black women), and ostensibly appear to be increasing in their pornography viewership at a sharper rate than others, their increasing likelihood of pornography viewership over time is only statistically different from white women, who show virtually no increase whatsoever over time in their likelihood of viewing pornography. 


\section{[TABLE 3 AND FIGURE 2 ABOUT HERE]}

Lastly, Table 4 examines how religious commitment potentially moderates the influence of race and gender on pornography viewership over time. Like Table 3, models include all controls from previous analyses, but these are left out to conserve space. Model 1 includes the interaction term with black $\times$ monthly attendance. While worship attendance is strongly and negatively associated with reporting pornography use in the main effect, the positive interaction term indicates that black Americans who are monthly worship attendees are slightly more likely to report viewing pornography than white Americans who are not monthly attendees. This suggests that religious commitment does not diminish pornography use for black Americans the way it does for white Americans, affirming our third hypothesis.

Models 2-4 consider the trends over time. Model 2 includes the full sample and triple interaction terms. With the other interaction terms included, the significant and negative interaction term for monthly attendance $\times$ year indicates that for white Americans, monthly attendance is negatively associated with viewing pornography across time, but not for black Americans. Model 3 includes only males and shows the same coefficient pattern, indicating that monthly worship attendance is a moderating factor for white men, but not black men. Model 4 includes only women and only the black $\times$ year interaction term is positive and significant, indicating that black women show an increasing rate of pornography viewership over time compared to white women, but religious service attendance did not moderate this relationship significantly.

Figure 3 clearly illustrates these trends. For white men, those who are monthly attendees show a flat rate of pornography viewership across waves of the GSS, while those who are not monthly attendees show a fairly sharp increasing rate. Black men and black women, by contrast, 
show fairly similar increasing rates of pornography viewership across worship attendance.

Moreover, white women show essentially flat rates of pornography viewership regardless of their frequency of worship attendance. Thus, the sixth hypothesis is only partially supported.

Religious commitment only moderated the pornography use of white men over time, but not black men, black women, or white women.

\section{[TABLE 4 AND FIGURE 3 ABOUT HERE]}

\section{Discussion and Conclusions}

The vast majority of previous research exploring the connection between race and pornography has focused almost exclusively on the "supply side" of pornography. That is, such studies have been primarily concerned with the sorts of racial messages that are expressed within pornographic material, what these messages reflect about broader social realities, and, for some, how these messages may influence society itself. By contrast, the question of how race potentially shapes the "demand side" of pornography—namely, who views pornography and how these patterns change-has been all but ignored. Drawing on nationally representative data from over four decades of the 1973-2016 GSS, and exploring the moderating influences of gender and religion, our study has sought to fill this gap. Our findings affirm previous research that black Americans in general are more likely to view pornography than white Americans, and we also document that this divergence has only increased over the past 43 years. Moreover, we show that black men in particular are more likely than all other race-gender groups to view pornography, though they are only statistically different from white women in their increasing rate of pornography viewership. White men and black women, though less likely to view pornography than black men, are also increasing in their likelihood to view pornography at a rate that is statistically indistinguishable from black men. Lastly, while religious commitment is 
generally thought to inhibit pornography use among Americans in general, our results indicate that more frequent worship attendance only seems to moderate the pornography use of white Americans in general and white men over time.

The findings of our study extend research on the intersections of race, gender, religion, and sexuality in several important ways. Although we cannot definitively demonstrate the social psychological mechanisms influencing Americans' choices regarding pornography viewership, our findings are largely consistent with our theoretical argument that black Americans, and black men in particular, hold fewer internalized norms against viewing pornography than other Americans. What is the source of these differences? Because we feel there is little scientific evidence to support the notion that essential race (and sex) differences drive the differential consumption patterns, and because our analyses look at adults and control for relevant sociodemographic characteristics, we feel that theories emphasizing broader cultural influences on sexual norms and behaviors are more promising. Specifically, we propose the most likely source of these differences are the divergent historical and subcultural experiences with pornography at the community level that have influenced white Americans to find pornography more morally objectionable than black Americans (see Lykke \& Cohen, 2015; Patterson \& Price, 2012; Sherkat \& Ellison, 1997; Wood \& Hughes, 1984). Pornography has never been a key moral issue for the black community, and thus, black Americans would predictably hold fewer internalized norms against viewing pornography, and this would explain their greater likelihood of viewing pornography relative to whites. Additionally, while the influence of gender socialization theory helps explain why men are more likely to access pornography than women, the combination of both racial and gender influences on black male sexuality helps explain why black men were the most likely to view pornography than all other race-gender groups. 
The intersecting influences of racial and gender socialization resulting in differential patterns of pornography consumption can also help us understand our findings showing divergent rates of pornography viewership over time. We proposed that the groups who would be least likely to internalize various anti-pornography norms, due to various influences, would evidence a higher rate of pornography viewership over time in response to pornography's everincreasing accessibility and acceptability. Findings mostly supported this theory. Black Americans showed a higher rate of increase in their pornography viewership compared to whites, and men showed a higher rate of increase in their pornography viewership over time compared to women. The partial exception to this was that black men did not differ from white men or black women in their increasing rate of pornography viewership over time, but only differed from white women. But even this lends partial support to the theory since black men (potentially being influenced by the combination of racial and gender factors) differed considerably from the racegender group who would receive the strongest combination of influences to avoid pornography, namely, white women. For white women, even as the "supply" of pornography has increased due to the Internet and smartphone technology, it has met with an essentially flat "demand" resulting in no increase in pornography viewership over time.

Lastly, one of the key influences we identified in shaping the historical relationship between white Americans and pornography relative to black Americans is religion. While white Protestants and Catholics have rallied political opposition against pornography for decades (Sherkat \& Ellison, 1997; Strub, 2011), while black Protestants have not taken a strong moral stance against it (Patterson \& Price, 2012; Wood \& Hughes, 1984). Part of the reason may be because white Americans tend to connect religious commitment and conservatism to their sexual behavior more so than black Americans, and particularly black men (Bearman \& Bruckner, 
2001; McCree et al. 2003; Regnerus, 2007; Steinman \& Zimmerman, 2004). At the individual level, our study shows that it is white men for whom religious commitment seems most to influence their pornography viewership over time. Regardless of worship frequency, black men and women seemed to show increasing rates of pornography viewership over time, while white women, because they were so unlikely to view pornography in the first place, showed no increase in their pornography viewership over time. Thus, religious commitment primarily constrains the sexual consumption of white men, while white women seem averse to view pornography for reasons beyond religious commitment.

Several data limitations are worth acknowledging in order to chart a path for future research. As mentioned in the methods section, while the GSS represents the only representative data set that includes a measure of pornography consumption over several decades, the pornography use measure is unfortunately limited in several ways. Most prominently, the question only asks about whether a respondent viewed pornography at all rather than how frequently the viewed it. Thus, we cannot discern whether black or white women or men view pornography more frequently than any other group, and whether such patterns have changed following the emergence of the Internet. Secondly, the wording of the question (about viewing an "X-rated movie") is rather dated reflecting nomenclature from the early 1970s when the question was first asked. Unfortunately, the greatest strength of the GSS - the continuity of its measures over time-is sometimes its greatest weakness. Even so, while most Americans likely do not refer to pornographic material as "X-rated" anymore, they almost certainly know what the term means (Whitehead \& Perry, 2017), and thus this limitation is not so serious. A related limitation is that the GSS measures of race dating back to 1973 only allow for a meaningful comparison between whites and blacks. Other cross-sectional studies have identified some 
differences in pornography viewership for other racial or ethnic groups like Hispanics (Hennessy et al., 2009) and Asians (Perry, 2016), and thus future studies would ideally include these measures as well. Again, the GSS represents the only data source that could be used for the current study, and thus, these limitations are unfortunately unavoidable.

It is worth speculating about where the patterns observed in this study may lead. To the extent that America is becoming more secular, and white Americans are becoming more accepting of pornography use and thus inculcating white women and men with fewer moral strictures against pornography viewership, all the while also rejecting stereotypes about white femininity that likely constrain the pornography viewing of white women, the differences observed here across racial and gender lines may disappear. Conversely, it seems we are witnessing a resurgence of hegemonic masculinity in the United States, among white men especially, but also across ethnic and racial lines (e.g., Stockman, 2017). As gendered (and racialized) tropes about male and female sexuality continue, it is possible that the different pornography use patterns observed here will remain or grow even more divergent. Relatedly, because different rates of pornography viewership over time seemed similarly pronounced across racial and gender lines (see Figure 1), it will be worth tracking which differences appear to be converging first and whether this suggests that sexual consumption patterns are becoming less gender- or race-specific. 


\section{REFERENCES}

Amoah, J. D. (1994). Black on the auction block: A discussion of black women and pornography. National Black Law Journal, 14, 204.

Bearman, P. S., \& Bruckner, H. (2001). Promising the future: Virginity pledges and first intercourse. American Journal of Sociology, 106, 859-912.

Bernardi, D. (2007). Racism and pornography: Evidence, paradigms, and publishing. Cinema Journal, 46(4), 116-121.

Brown, J. D., \& L'Engle, K. L. (2009). Sexual attitudes and behaviors associated with U.S. early adolescents' exposure to sexually explicit media. Communication Research, 36(1), 129151.

Buzzell, T. (2005). Demographic characteristics of persons using pornography in three technological contexts. Sexuality \& Culture, 9(1), 28-48.

Carroll, J. S., Padilla-Walker, L. M., Nelson, L. J., Olson, C. D., McNamara Barry, C., \& Madsen, S. D. (2008). Generation XXX: Pornography acceptance and use among emerging adults. Journal of Adolescent Research, 23, 6-30.

Collins, P. H. (2000). Black feminist thought: Knowledge, consciousness, and the politics of empowerment. Second Edition. New York: Routledge.

Collins, P. H. (2004). Black sexual politics: African Americans, gender, and the new racism. New York: Routledge.

Cowan. G. (1995). Black and white (and blue): Ethnicity and pornography. In Bringing Cultural Diversity to Feminist Psychology: Theory, Research, Practice. H. Landrine (Edt.) (pp. 397-411). Washington, DC: American Psychological Association.

Cowan, G., \& Campbell, R. R. (2004). Racism and sexism in interracial pornography: A content 
analysis. Psychology of Women Quarterly, 18(3), 323-338.

Dines, G. (1998). King Kong and the white woman: Hustler magazine and the demonization of black masculinity. Violence Against Women, 4(3), 291-307.

Dines, G. (2006). The white man's burden: Gonzo pornography and the construction of black masculinity. Yale Journal of Law \& Feminism, 18, 283-298.

Dines, G. (2010). Pornland: How porn has hijacked our sexuality. Boston: Beacon.

Dines, G., \& Humez, J. M. (2011). Gender, race, and class in media: A critical reader. Third Edition. Thousand Oaks: Sage.

Doran, K., \& Price, J. (2014). "Pornography and marriage." Journal of Family and Economic Issues 35(4):489-498.

Forna, A. (1992). “Pornography and racism: Sexualizing oppression and inciting hatred. In Pornography: Women, Violence, and Civil Liberties (pp. 102-112).

Grubbs, J. B., Exline, J. J., Pargament, K. I., Hook, J. N., \& Carlisle, R. D. (2015). Transgression as addiction: Religiosity and moral disapproval as predictors of perceived addiction to pornography. Archives of Sexual Behavior, 44, 125-136.

Guo, G, Fu, Y., Lee, H., Cai, T., Harris, K. M., \& Li, Y. (2014). Genetic bio-ancestry and social construction of racial classification of social surveys in the contemporary United States. Demography 61(1):141-172.

Hald, G. M. (2006). Gender differences in pornography consumption among young heterosexual Danish adults. Archives of Sexual Behavior, 35, 577-585

Hardy, S. A., Steelman, M. A., Coyne, S. M., \& Ridge, R. D. (2013). Adolescent religious as a protective factor against pornography use. Journal of Applied Developmental Psychology, 34(3), 131-139. 
Hennessy, M., Bleakley, A., Fishbein, M., \& Jordan, A. (2009). Estimating the longitudinal association between adolescent sexual behavior and exposure to sexual media content. Journal of Sex Research, 46(6), 586-596.

Jensen, R. (2007). Getting off: Pornography and the end of masculinity. Cambridge, MA: South End.

Johansson, T., \& Hammaren, N. (2007). Hegemonic masculinity and pornography: Young people's attitudes toward and relations to pornography. Journal of Men's Studies, 15(1), $57-70$.

Lykke, L. C., \& Cohen, P. N. (2015). The widening gender gap in opposition to pornography, 1975-2012. Social Currents, 2(4), 307-323.

Mayall, A., \& Russell, D. (1993). Racism in pornography. Feminism \& Psychology, 3(2), 275281.

Miller-Young, M. (2007). Hip-hop honeys and da hustlaz: Black sexualities in the new hip-hop pornography. Meridians: Feminism, Race, Transnationalism, 8(1), 261-292.

Miller-Young, M. (2010). Putting hypersexuality to work: Black women and illicit eroticism in pornography. Sexualities, 13(2), 219-235.

Miller-Young, M. (2014). A taste for brown sugar: Black women in pornography. Durham: Duke University Press.

Morning, A. (2014). And you thought we had moved beyond all that: Biological race returns to the social sciences. Ethnic and Racial Studies, 37(10), 1676-1685.

Nash, J. C. (2014). The black body in ecstasy: Reading race, reading pornography. Durham: Duke University Press.

Nelson, L. J., Padilla-Walker, L. M., \& Carroll, J. S. (2010). "I believe it is wrong but I still do 
it": A comparison of religious young men who do versus do not use pornography. Psychology of Religion and Spirituality, 2, 136-147.

Patterson, R., \& Price, J. (2012). "Pornography, Religion, and the Happiness Gap: Does Pornography Impact the Actively Religious Differently?” Journal for the Scientific Study of Religion, 51(1), 79-89.

Pattillo-McCoy, M. (1998). Church culture as a strategy of action in the black community. American Sociological Review, 63(6), 767-784.

Perry, S. L. (2016). From bad to worse? Pornography consumption, spousal religiosity, gender, and marital quality. Sociological Forum, 31, 441-464.

Perry, S. L. (2017a). Not practicing what you preach: Religion and incongruence between pornography beliefs and usage. Journal of Sex Research. doi:

$10.1080 / 00224499.2017 .1333569$

Perry, S. L. (2017b). Spousal religiosity, religious bonding, and pornography consumption. Archives of Sexual Behavior, 46(2), 561-574.

Perry, S. L., \& Schleifer, C. (2017). Till porn do us part? A longitudinal examination of pornography use and divorce. Journal of Sex Research. doi: $10.1080 / 00224499.2017 .1317709$

Peter, J., \& Valkenburg, P. M. (2011). The use of sexually explicit internet material and its antecedents: A longitudinal comparison of adolescents and adults. Archives of Sexual Behavior, 40, 1015-1025.

Peterson, J. L., \& Hyde, J. S. (2011). Gender differences in sexual attitudes and behaviors: A review of meta-analytic results and large datasets. Journal of Sex Research, 48, 149-165.

Poulsen, F. O., Busby, D. M., \& Galovan, A. M. (2013). Pornography use: Who uses it and how 
it is associated with couple outcomes. Journal of Sex Research, 50, 72-83.

Price, J., Patterson, R., Regnerus, M., \& Walley, J. (2016). How much more XXX is Generation $\mathrm{X}$ consuming? Evidence of changing attitudes and behaviors related to pornography since 1973. Journal of Sex Research, 53(1), 12-20.

Regnerus, M. D. (2007). Forbidden fruit: Sex and religion in the lives of American teenagers. New York: Oxford University Press.

Regnerus, M., Gordon, D., \& Price, J. (2016). Documenting pornography use in America: A comparative analysis of methodological approach. Journal of Sex Research 53(7):873881.

Schleifer, C., \& Chaves, M. (2017). Family formation and religious service attendance: Untangling marital and parental effects. Sociological Methods \& Research 46(1):125152.

Shelton, J. E., \& Emerson, M. O. (2012). Blacks and whites in Christian America: How racial discrimination shapes religious convictions. New York: NYU Press.

Sherkat, D. E., Ellison, C. G. (1997). The cognitive structure of a moral crusade: Conservative Protestantism and opposition to pornography. Social Forces, 75, 957-980.

Shiao, J. L., Bode, T., Beyer, A., \& Selvig, D. (2012). The genomic challenge to the social construction of race. Sociological Theory, 30(2), 67-88.

Short, M. B., Kasper, T. E., \& Wetterneck, C. T. (2015). The relationship between religiosity and internet pornography use. Journal of Religion and Health, 54, 571-583.

Smith, J. G., \& Luykx, A. (2017). Race play in bdsm porn: The eroticization of oppression. Porn Studies, 16, 1-14

Steensland, B., Park, J. Z., Regnerus, M. D., Robinson, L., Wilcox, W. B., \& Woodberry, R. 
(2000). The measure of American religion: Toward improving the state of the art. Social Forces, 79, 291-318.

Steinman, K. J., \& Zimmerman, M. A. (2004). Religious activity and risk behavior among African American adolescents: Concurrent and developmental effects. American Journal of Community Psychology, 33, 151-161.

Stockman, F. (2017). Women's march on Washington opens contentious dialogues about race. New York Times, January $9^{\text {th }}$. https://www.nytimes.com/2017/01/09/us/womens-marchon-washington-opens-contentious-dialogues-about-race.html.

Strub, W. (2011). Perversion for profit: The politics of pornography and the rise of the new right. New York: Columbia University Press.

Thomas, J. N. (2013). Outsourcing moral authority: The internal secularization of evangelicals' anti-pornography narratives. Journal for the Scientific Study of Religion, 52(3), 457-475.

Whitehead, A. L., \& Perry, S. L. (2017). Unbuckling the Bible belt: A state-level analysis of religious factors and Google searches for porn. Journal of Sex Research. doi: 10.1080/00224499.2017.1278736

Wood, M., \& Hughes, M. (1984). The moral basis of moral reform: Status discontent vs. culture and socialization as explanation of anti-pornography social movement adherence. American Sociological Review, 49(1), 86-99.

Wright, P. J. (2013). U.S. males and pornography, 1973-2010: Consumption, predictors, and correlates. Journal of Sex Research, 50, 60-71.

Wright, P. J., Bae, S., \& Funk, M. (2013). United States women and pornography through four decades: Exposure, attitudes, behaviors, and individual differences. Archives of Sexual Behavior, 42, 1131-1144. 


\section{TABLES}

Table 1. Summary Statistics by Race

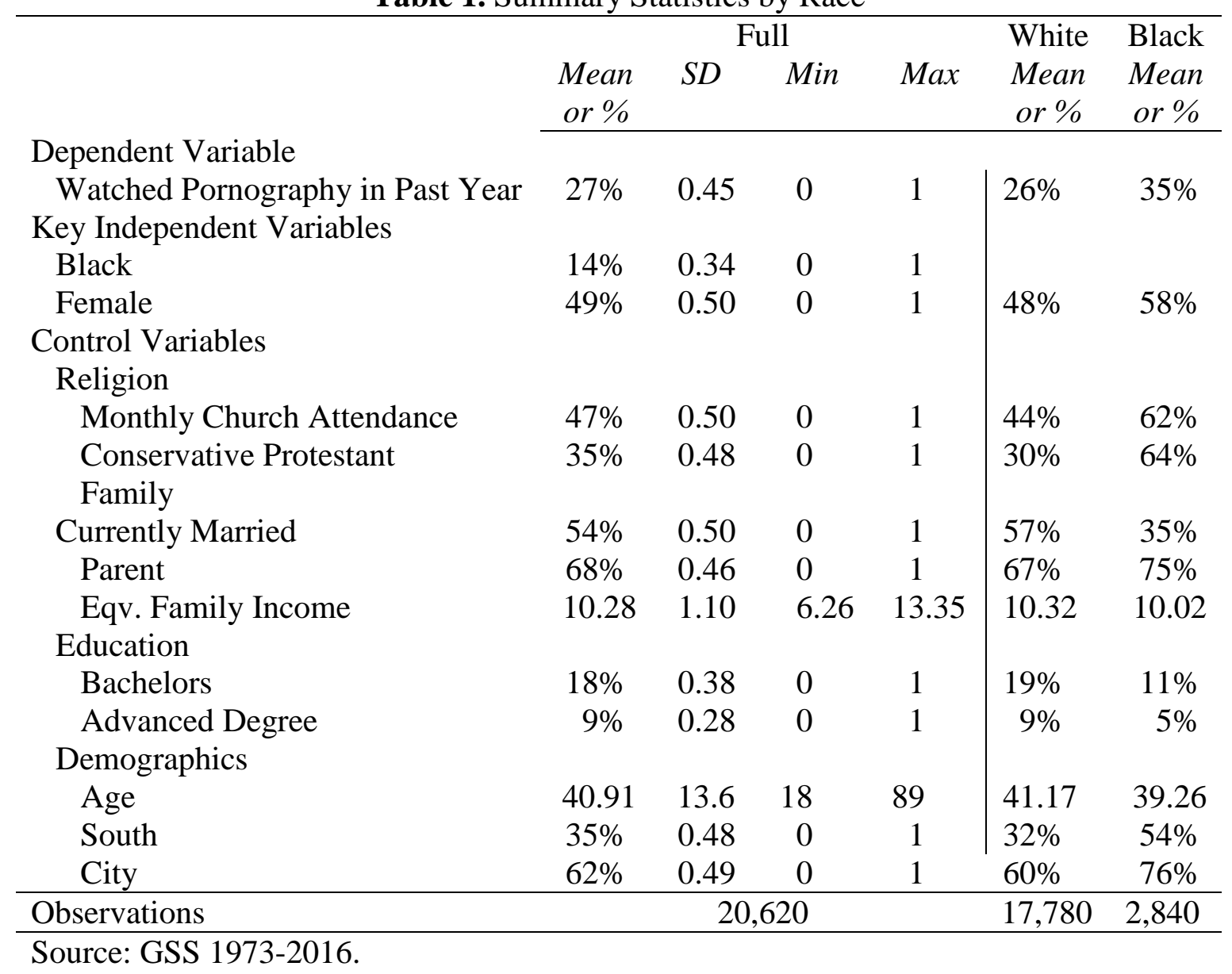


Table 2. Logistic Regressions of Pornography Usage by Intersection of Race and Gender, 1973-2016

\begin{tabular}{|c|c|c|c|c|}
\hline \multicolumn{5}{|c|}{ (in Log Odds) } \\
\hline \multirow{3}{*}{ Black } & Model 1 & Model 2 & Model 3 & Model 4 \\
\hline & $0.582^{* * *}$ & $0.404^{* * *}$ & $0.589^{* * *}$ & $0.357^{* * *}$ \\
\hline & $(.05)$ & $(.10)$ & $(.05)$ & $(.10)$ \\
\hline \multirow[t]{2}{*}{ Female } & $-0.812^{* * *}$ & $-0.812^{* * * *}$ & $-0.436^{* * * *}$ & $-0.421^{* * * *}$ \\
\hline & $(.04)$ & $(.04)$ & $(.07)$ & $(.07)$ \\
\hline \multirow[t]{2}{*}{ Year of Survey } & $0.013^{* * *}$ & $0.011^{* * *}$ & $0.020^{* * *}$ & $0.018^{* * *}$ \\
\hline & $(.00)$ & $(.00)$ & $(.00)$ & $(.00)$ \\
\hline \multicolumn{5}{|l|}{$\underline{\text { Interactions }}$} \\
\hline Black*Year & & $\begin{array}{l}0.008^{*} \\
(.00)\end{array}$ & & $\begin{array}{l}0.010^{* *} \\
(.00)\end{array}$ \\
\hline Female*Year & & & $\begin{array}{c}-0.017^{* * *} \\
(.00)\end{array}$ & $\begin{array}{c}-0.018^{* * *} \\
(.00)\end{array}$ \\
\hline \multicolumn{5}{|l|}{ Controls } \\
\hline \multicolumn{5}{|l|}{ Religion } \\
\hline Monthly Church Attendance & $\begin{array}{c}-0.697^{* * *} \\
(.04)\end{array}$ & $\begin{array}{c}-0.699^{* * *} \\
(.04)\end{array}$ & $\begin{array}{c}-0.702^{* * *} \\
(.04)\end{array}$ & $\begin{array}{c}-0.704^{* * *} \\
(.04)\end{array}$ \\
\hline Conservative Protestant & $\begin{array}{c}-0.148^{* * *} \\
(.04)\end{array}$ & $\begin{array}{c}-0.146^{* * *} \\
(.04)\end{array}$ & $\begin{array}{c}-0.143^{* * *} \\
(.04)\end{array}$ & $\begin{array}{c}-0.140^{* * *} \\
(.04)\end{array}$ \\
\hline \multicolumn{5}{|l|}{ Family Characteristics } \\
\hline Currently Married & $\begin{array}{c}-0.224^{* * *} \\
(.04)\end{array}$ & $\begin{array}{c}-0.224^{* * *} \\
(.04)\end{array}$ & $\begin{array}{c}-0.224^{* * *} \\
(.04)\end{array}$ & $\begin{array}{c}-0.223^{* * *} \\
(.04)\end{array}$ \\
\hline Parent & $\begin{array}{c}-0.060 \\
(.04)\end{array}$ & $\begin{array}{r}-0.061 \\
(.04)\end{array}$ & $\begin{array}{r}-0.054 \\
(.04)\end{array}$ & $\begin{array}{c}-0.054 \\
(.04)\end{array}$ \\
\hline Eqv. Family Income & $\begin{array}{c}0.012 \\
(.02)\end{array}$ & $\begin{array}{c}0.012 \\
(.02)\end{array}$ & $\begin{array}{c}0.017 \\
(.02)\end{array}$ & $\begin{array}{c}0.018 \\
(.02)\end{array}$ \\
\hline \multicolumn{5}{|l|}{ Education } \\
\hline Bachelors & $\begin{array}{c}-0.211^{* * *} \\
(.05)\end{array}$ & $\begin{array}{c}-0.210^{* * *} \\
(.05)\end{array}$ & $\begin{array}{c}-0.209^{* * *} \\
(.05)\end{array}$ & $\begin{array}{c}-0.208^{* * *} \\
(.05)\end{array}$ \\
\hline Advanced Degree & $\begin{array}{c}-0.277^{* * * *} \\
(.07)\end{array}$ & $\begin{array}{c}-0.277^{* * * *} \\
(.07)\end{array}$ & $\begin{array}{c}-0.269^{* * * *} \\
(.07)\end{array}$ & $\begin{array}{c}-0.269^{* * * *} \\
(.07)\end{array}$ \\
\hline \multicolumn{5}{|l|}{ Demographics } \\
\hline Age & $\begin{array}{c}-0.006 \\
(.01)\end{array}$ & $\begin{array}{c}-0.006 \\
(.01)\end{array}$ & $\begin{array}{r}-0.007 \\
(.01)\end{array}$ & $\begin{array}{r}-0.007 \\
(.01)\end{array}$ \\
\hline Age2 & $\begin{array}{c}-0.000^{* * * *} \\
(.00)\end{array}$ & $\begin{array}{c}-0.000^{* * *} \\
(.00)\end{array}$ & $\begin{array}{c}-0.000^{* * *} \\
(.00)\end{array}$ & $\begin{array}{c}-0.000^{* * *} \\
(.00)\end{array}$ \\
\hline South & $\begin{array}{r}-0.015 \\
(.04)\end{array}$ & $\begin{array}{c}-0.016 \\
(.04)\end{array}$ & $\begin{array}{r}-0.015 \\
(.04)\end{array}$ & $\begin{array}{r}-0.017 \\
(.04)\end{array}$ \\
\hline City & $\begin{array}{l}0.082^{*} \\
(.04)\end{array}$ & $\begin{array}{l}0.085^{*} \\
(.04)\end{array}$ & $\begin{array}{c}0.078^{*} \\
(.04)\end{array}$ & $\begin{array}{l}0.081^{*} \\
(.04)\end{array}$ \\
\hline$N$ & \multicolumn{4}{|c|}{20,620} \\
\hline
\end{tabular}


Table 3. Logistic Regressions of Pornography Usage with Race and Gender Trends

Interactions, 1973-2016 ${ }^{1}$

(in Log Odds)

\begin{tabular}{|c|c|c|}
\hline & Model $1^{2}$ & Model $2^{3}$ \\
\hline $\begin{array}{l}\text { White Female (ref.) } \\
\text { White Male }\end{array}$ & $\begin{array}{l}0.796^{* * *} \\
(.04)\end{array}$ & $\begin{array}{l}0.375^{* * *} \\
(.08)\end{array}$ \\
\hline Black Female & $\begin{array}{l}0.535^{* * * *} \\
(.07)\end{array}$ & $\begin{array}{l}0.190 \\
(.15)\end{array}$ \\
\hline Black Male & $\begin{array}{l}1.425^{* * *} \\
(.07)\end{array}$ & $\begin{array}{l}0.885^{* * *} \\
(.14)\end{array}$ \\
\hline Year of Survey & $\begin{array}{l}0.013^{* * *} \\
(.00)\end{array}$ & $\begin{array}{r}-0.001 \\
(.00)\end{array}$ \\
\hline $\begin{array}{l}\text { Interactions } \\
\text { White Male*Year }\end{array}$ & & $0.020^{* * * *}$ \\
\hline Black Female*Year & & $\begin{array}{l}(.00) \\
0.016^{* *} \\
(.01)\end{array}$ \\
\hline Black Male*Year & & $\begin{array}{l}0.025^{* * *} \\
(.01)\end{array}$ \\
\hline$N$ & \multicolumn{2}{|c|}{20,620} \\
\hline $\begin{array}{l}\text { Source: GSS } 1973-2010 \\
\dagger p<.10,{ }^{*} p<.05,{ }^{* *} p \\
\text { Standard errors in parer } \\
{ }^{1} \text { Each model also contr } \\
\text { characteristics, educatio } \\
\text { These are excluded to c } \\
{ }^{2} \text { Regression coefficient } \\
\text { different from one anot } \\
{ }^{3} \text { Ancillary analyses sho } \\
\text { only significantly differ } \\
\text { not each other. }\end{array}$ & $\begin{array}{l}.01,{ }^{* * *} p< \\
\text { heses } \\
\text { s for religio } \\
\text { and demo } \\
\text { hserve space } \\
\text { are all signi } \\
\text { r beyond .0 } \\
\text { interaction } \\
\text { ht from whi }\end{array}$ & $\begin{array}{l}\text { 01; } \\
\text {, family } \\
\text { raphics. } \\
\text { icantly } \\
1 \text { level. } \\
\text { terms } \\
\text { e females, }\end{array}$ \\
\hline
\end{tabular}


Table 4. Logistic Regressions of Pornography Usage by Race and Gender, over Religious Service Attendance ${ }^{1}$

(in Log Odds)

\begin{tabular}{lcccc}
\hline & Full & Trend & Male & Female \\
\hline Black & $0.494^{* * *}$ & $0.274^{\dagger}$ & $0.438^{*}$ & 0.048 \\
& $(.07)$ & $(.15)^{* *}$ & $(.19)^{* * *}$ & $(.23)$ \\
Monthly Attender & $-0.726^{* * *}$ & $-0.521^{* * *}$ & $-0.461^{* * *}$ & $-0.622^{* * *}$ \\
& $(.04)$ & $(.08)^{* * *}$ & $(.10)$ & $(.12)$ \\
Female & $-0.814^{* * *}$ & $-0.815^{* * *}$ & & \\
& $(.04)$ & $(.04)^{* * *}$ & & \\
Survey Year & $0.013^{* * *}$ & $0.015^{* * *}$ & $0.021^{* * *}$ & 0.004 \\
& $(.00)$ & $(.00)$ & $(.00)$ & $(.00)$ \\
Interactions & & & & \\
Black*Monthly & $0.169^{\dagger}$ & 0.163 & 0.106 & 0.199 \\
& $(.09)$ & $(.20)$ & $(.28)$ & $(.30)$ \\
Black*Year & & $0.009^{\dagger}$ & 0.005 & $0.017^{*}$ \\
& & $(.01)$ & $(.01)$ & $(.01)$ \\
Monthly*Year & & $-0.010^{* *}$ & $-0.012^{* *}$ & -0.007 \\
& & $(.00)$ & $(.00)$ & $(.01)$ \\
Black*Monthly*Year & & 0.002 & 0.003 & 0.002 \\
& & $(.01)$ & $(.01)$ & $(.01)$ \\
\hline$N$ & 20,620 & 20,620 & 10,434 & 10,186 \\
\hline
\end{tabular}

Source: GSS 1973-2016

Standard errors in parentheses; ${ }^{\dagger} p<.10,{ }^{*} p<.05,{ }^{* *} p<.01,{ }^{* * *} p<.001$ ${ }^{1}$ Each model also controls for religion, family characteristics, education, and demographics. These are excluded to conserve space. 


\section{FIGURES}

Figure 1. Trends in Pornography Consumption Across Race and Gender, 1973-2016

Race

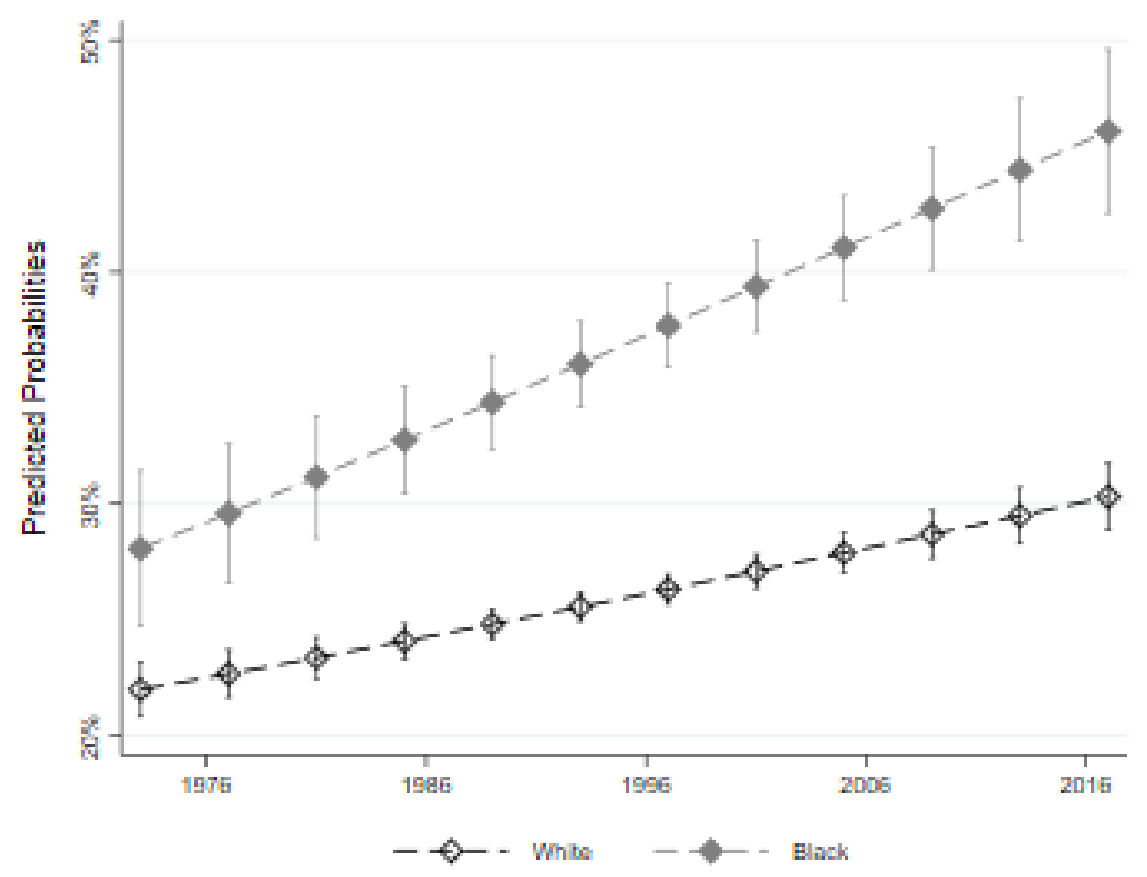

Gender

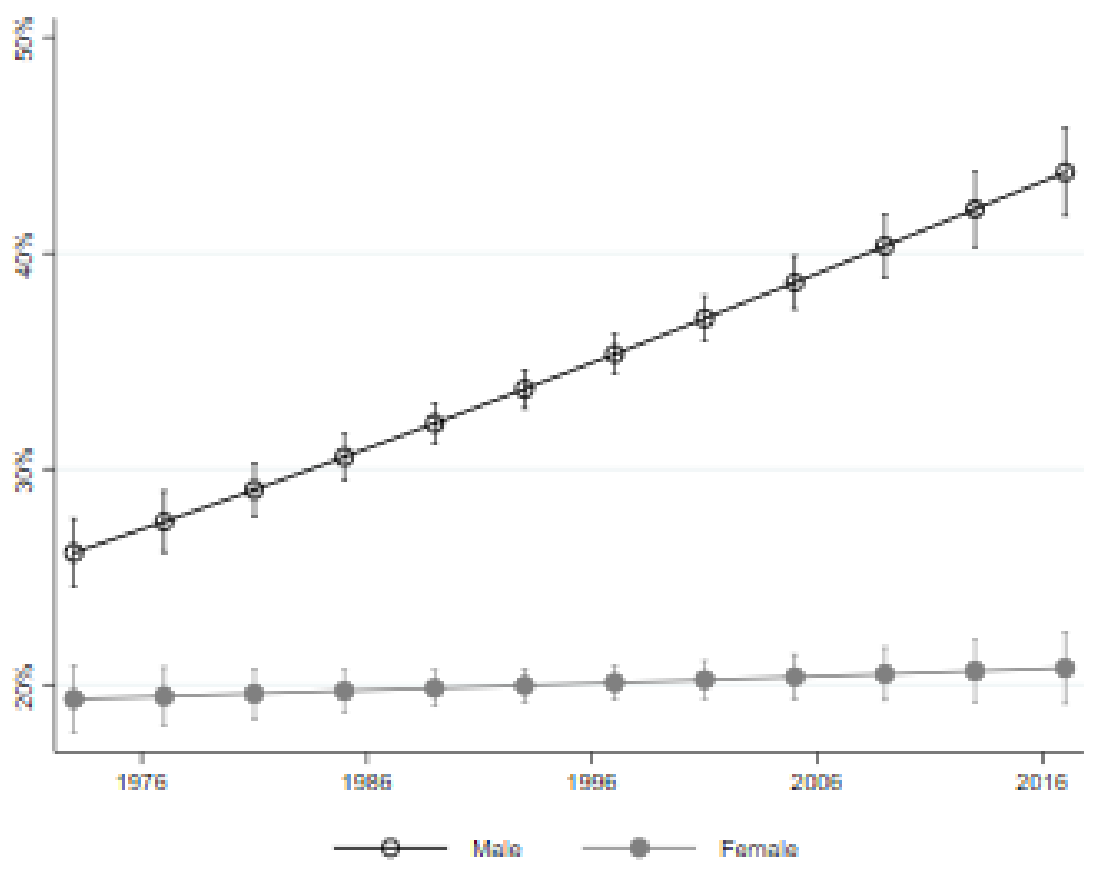


Figure 2. Trends in Pornography Consumption with Race and Gender Interaction, 1973-2016

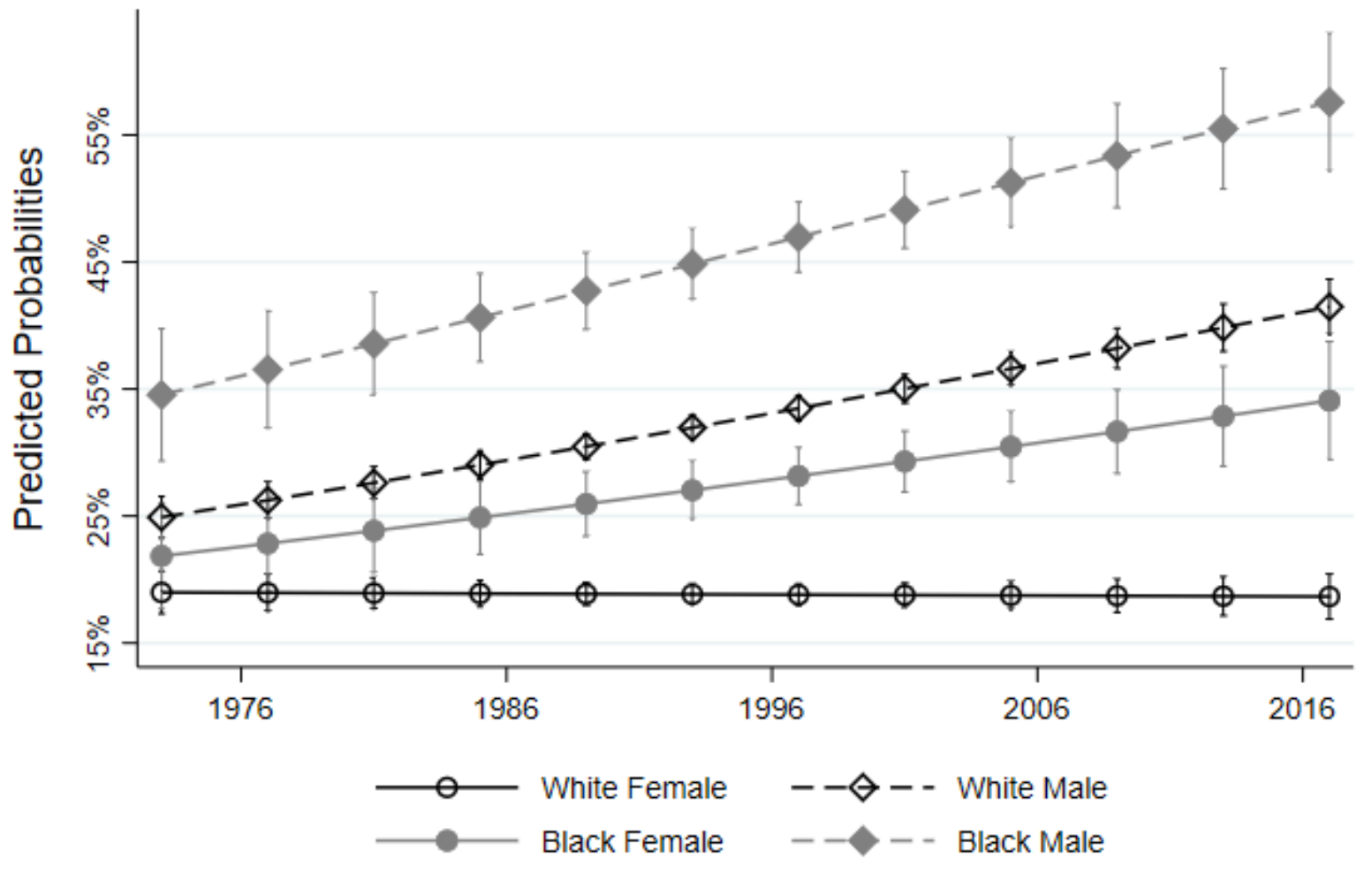


Figure 3. Trends in Pornography Consumption by Race and Gender over Monthly Religious Service Attendance Males

White

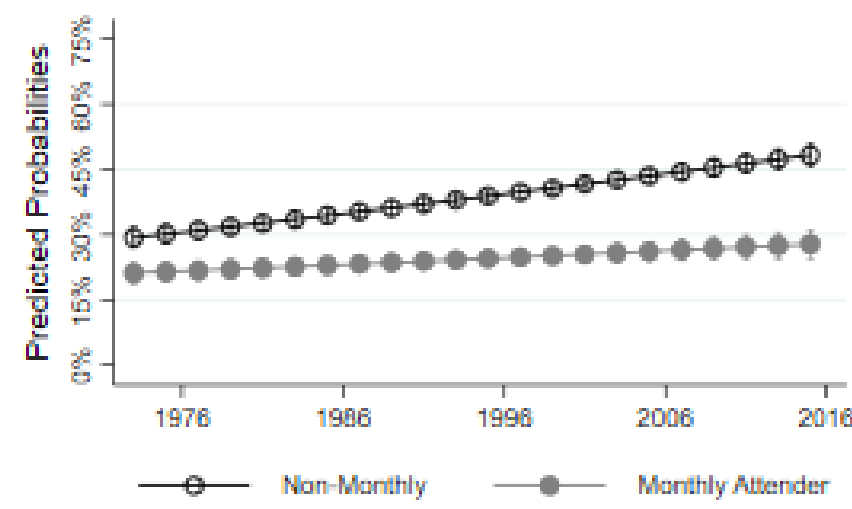

Black

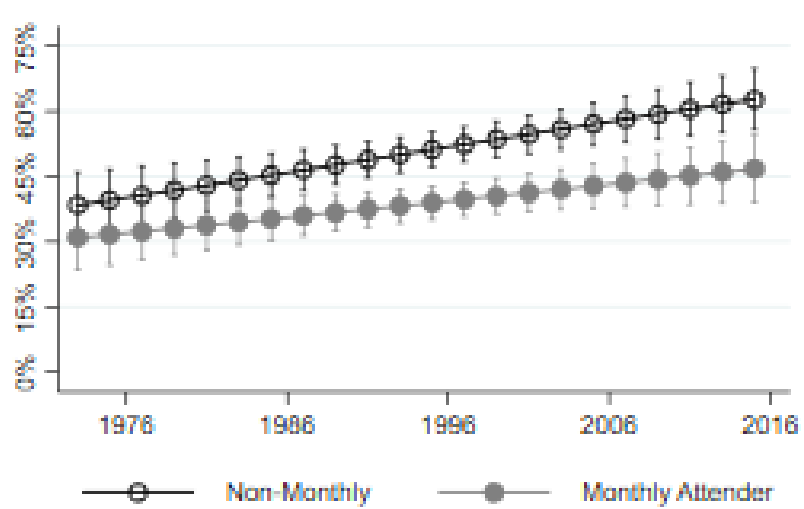

Black

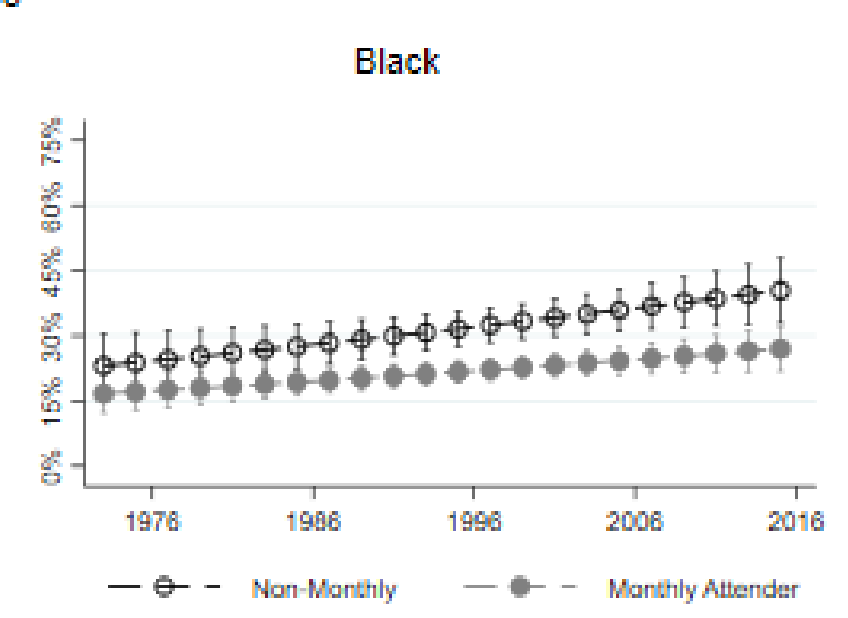

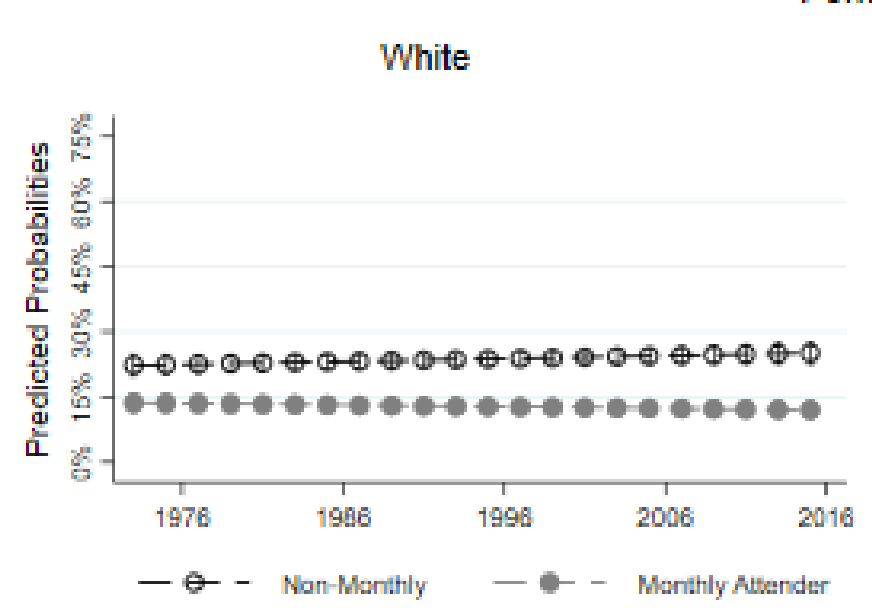

Females

White

.

